Int. J. Electrochem. Sci., 14 (2019) 10469 - 10489

International Journal of

ELECTROCHEMICAL

SCIENCE

$\underline{\text { www.electrochemsci.org }}$

\title{
Performance and Aging Study of a Proton Exchange Membrane with Different Materials at Different Temperatures and Humidities
}

\author{
Bai Qiang ${ }^{1}$, Li Shaobo ${ }^{1, *}$, Chuang-Yu Hsieh ${ }^{2}$, Fang-Bor Weng ${ }^{3}$, Hsiou-Ming Ou ${ }^{3}$ \\ ${ }^{1}$ College of Mechanical Engineering, Guizhou University, Guiyang 550000, P R China; \\ ${ }^{2}$ Department of Automotive Engineering, Tsinghua University, Beijing 100084, P R China; \\ ${ }^{3}$ Department of Mechanical Engineering \& Fuel Cell Center, Yuan Ze University, Taoyuan 320, \\ Taiwan \\ *E-mail: lishaobo@gzu.edu.cn
}

doi: $10.20964 / 2019.11 .54$

Received: 29 May 2019 / Accepted: 10 September 2019 / Published: 7 October 2019

\begin{abstract}
By changing the material for a membrane electrode assembly (MEA) of a fuel cell and controlling the mode of gas inflow, along with the working temperature and humidity, the performance change of the fuel cell and the aging of the MEA under low humidity were studied. It was found that with the decrease of humidity from $100 \% \mathrm{RH}$ to $50 \% \mathrm{RH}$, the decline of cell performance ranged from $8.4 \%$ to $64 \%$. Due to the hydrophilicity of silicon dioxide $\left(\mathrm{SiO}_{2}\right)$, the addition of $\mathrm{SiO}_{2}$ into the MEA helped the membrane have better water retention; the current density greatly increased with a decline of cell performance that ranged from $17 \%$ to $44 \%$ at $50 \% \mathrm{RH}$. After the area of the MEA was increased, it was found that with a decrease of relative humidity, the performance decreased by $21 \%-36 \%$. Under $100 \%$ RH and after a 100-h cyclic dynamic load aging test, the performance decline of fuel cells was $27.2 \%$ and the performance decline of the ECSA was $33.3 \%$. Under $50 \% \mathrm{RH}$, the performance decrease was $51.8 \%$ and the ECSA decrease was 55.3\%. The impedance increase and the fluctuating decrease of the OCV of fuel cells under $100 \% \mathrm{RH}$ were obviously less than those under $50 \% \mathrm{RH}$.
\end{abstract}

Keywords: Humidity; Silicon Dioxide; Membrane Aging; Performance Decline

\section{FULL TEXT}

(C) 2019 The Authors. Published by ESG (www.electrochemsci.org). This article is an open access article distributed under the terms and conditions of the Creative Commons Attribution license (http://creativecommons.org/licenses/by/4.0/). 